\title{
COVID-19; Experience at the National Institute of Infectious Diseases, Sri Lanka
}

\author{
Idampitiya $D^{1}$, Narangoda $E^{1}$, Pahalagamage $S^{1}$, Wijewickrama $A^{1^{*}}$
}

Journal of the Ceylon College of Physicians, 2020, 51, 58-62

\section{Introduction}

The corona virus disease (COVID-19), first identified in Wuhan, China in December 2019, was declared a Public Health Emergency of International Concern on $30^{\text {th }}$ January by the World Health Organization $(\mathrm{WHO})$ and later as a pandemic on $11^{\text {th }}$ March $2020^{1}$

The National Institute of Infectious Diseases (NIID) of Sri Lanka, the single specialized hospital for communicable diseases in the country is the main hospital designated for COVID-19 management. The policy of the Ministry of Health $(\mathrm{MoH})$ requires that all COVID-19 positive patients are admitted to hospitals to facilitate monitoring and to prevent the spread of the disease to the community. Since late-January 2020, all individuals who were suspected of COVID-19 were admitted to the NIID. As the patient numbers were rising, $\mathrm{MoH}$ designated several other hospitals to accommodate COVID-19 suspected individuals and five other hospitals for management of confirmed cases.

The first patient reported in Sri Lanka was a Chinese national, diagnosed on the $27^{\text {th }}$ January while the first local patient was reported on $11^{\text {th }}$ March 2020. Our initial patients were returnees from Italy and India. Their contacts were traced and admitted to NIID for observation. Subsequently, the Government of Sri Lanka took several immediate measures to curtail the spread of COVID-19 via imported cases. From 11th March 2020, those arriving from Italy, Iran and South
Korea were quarantined for a period of 14 days at the quarantine centres while other overseas returnees were subjected to self-quarantine. Later every person returned from overseas were admitted to quarantine centres for isolation. They were subjected to real time Reverse transcriptase polymerase chain reaction (RTPCR) tests for SARS-CoV-2 and once confirmed positive, were admitted to designated hospitals for isolation and management. Since late March, clusters of cases have been reported from several areas of the country. Currently the occurrence of cases is restricted to clusters and returnees from overseas. The upsurge of cases in mid-May was caused by a cluster which occurred in a Navy garrison, Welisara ${ }^{2}$.

By the $25^{\text {th }}$ May, 1055 of either suspected individuals or COVID-19 confirmed patients have been admitted to NIID. Of this 327 are were confirmed positive for SARS-CoV-2 by the real time RT-PCR analysis. Out of them 240 confirmed patients have been discharged from the hospital, while 6 patients have died.

\section{Patient characteristics}

Of the 327 confirmed cases, majority of patients (92.6\%) were between 20-59 years with a mean age of 39.06 years (SD 16.62). Most of the infected (71\%) were men. The male preponderance in COVID-19 infection, is reported from other countries across the globe. The youngest patient was 03 months old while the oldest was a 94 years old woman.

\footnotetext{
${ }^{1}$ National Institute of Infectious Diseases, Angoda, Sri Lanka.

*Correspondence: AW, e-mail: anandawijewickrama012@gmail.com
}

DD http://orcid.org/0000-0003-2723-1813

Received 28 May 2020, accepted 09 June 2020.

This is an open-access article distributed under the terms of the Creative Commons Attribution License, which permits unrestricted use, distribution, and reproduction in any medium, provided the original author and source are credited. 
Table 1. Age distribution of patients $(n=327)$

\begin{tabular}{cc}
\hline Age group & Number of patients \\
\hline 0-1 years & 03 \\
1-10 years & 17 \\
11-20 years & 22 \\
$21-30$ years & 72 \\
31-40 years & 83 \\
41-50 years & 60 \\
$51-60$ years & 36 \\
$61-70$ years & 21 \\
$71-80$ years & 10 \\
81-90 years & 02 \\
$91-100$ years & 01 \\
\hline
\end{tabular}

\section{Co-morbidities}

In an interim analysis done on first 257 patients (including 6 deaths), 77 (29.9\%) had co-morbidities (Table 2). Hypertension and diabetes were the commonest co-morbidities. Out of 77 patients who had co-morbidities $49.3 \%$ had hypertension and $37.66 \%$ had diabetes mellitus. $45.4 \%$ were having two or more co-morbidities which is about $13.6 \%$ of the total population.

Table 2. Frequency of co-morbidities $(n=257)$

\begin{tabular}{ll}
\hline Comorbidity & Frequency $n(\%)$ \\
\hline Hypertension & $37(14.3)$ \\
Diabetes mellitus & $29(11.2)$ \\
Dyslipidaemia & $19(7.3)$ \\
Bronchial asthma & $16(6.2)$ \\
Ischemic heart disease & $13(5.0)$ \\
Cerebrovascular disease & $03(1.1)$ \\
Hypothyroidism & $03(1.1)$ \\
Chronic liver cell disease & $01(0.003)$ \\
Chronic obstructive pulmonary disease & $01(0.003)$ \\
Heart failure & $01(0.003)$ \\
Nephrotic syndrome & $01(0.003)$ \\
Bipolar affective disorder & $01(0.003)$ \\
Kidney transplant & $01(0.003)$ \\
Chronic cellulitis & $1(0.003)$ \\
Osteoarthritis & $1(0.003)$ \\
\hline
\end{tabular}

\section{Clinical features}

Cough, fever and sore throat were the commonest symptoms; 118 (45.9\%) patients had fever, 119 (46.3\%) had cough and 75 patients had both (Table 3). Sore throat was reported in $72(28 \%)$ patients. Interestingly, only $36(9 \%)$ of patients complained of dyspnoea as an initial symptom. Rhinorrhoea was reported in 43 $(16 \%)$ of patients while $18(7 \%)$ patients had anosmia. However, anosmia is likely to be an underestimate as this symptom was not inquired into during the early phase of the epidemic.

Table 3. Frequency of symptoms in 257 patients

\begin{tabular}{ll}
\hline Symptom & Number (\%) \\
\hline Cough & $119(46)$ \\
Fever & $118(46)$ \\
Sore throat & $72(28)$ \\
Headache & $59(23)$ \\
Myalgia & $53(20.6)$ \\
Rhinorrhoea & $43(16.7)$ \\
Dyspnoea & $36(14)$ \\
Diarrhoea & $36(14)$ \\
Nasal congestion & $26(10)$ \\
Chest pain & $26(10)$ \\
Dyspepsia & $24(9)$ \\
Loss of appetite & $23(8.9)$ \\
Anosmia & $19(7.3)$ \\
Fatigue & $18(7)$ \\
Loss of taste & $18(7)$ \\
Vomiting & $15(5.8)$ \\
Arthralgia & $13(5)$ \\
Abdominal pain & $12(4.6)$ \\
Dysgeusia & $9(3.5)$ \\
Nausea & $6(2.3)$ \\
Dysuria & $4(1.5)$ \\
Haemoptysis & $4(1.5)$ \\
Conjunctivitis & $3(1.1)$ \\
Pruritus & $3(1.1)$ \\
\hline & \\
\hline & \\
\hline
\end{tabular}




\section{Disease severity}

The disease severity was categorized as mild, severe and critical illness. Those without pneumonia and mild pneumonia cases were categorized as mild cases. Patients were identified as severe if they had dyspnoea, respiratory rate $\geq 30 /$ minute, blood oxygen saturation $\geq 93 \%$, $\mathrm{PaO} 2 / \mathrm{FiO} 2$ ratio $<300$, and/or lung infiltrates $>50 \%$ within $24-48$ hours. Critical cases were those who had respiratory failure, septic shock, and/ or multiple organ dysfunction/failure ${ }^{3}$.

Out of the first 100 patients who were discharged from the hospital or died, $92.0 \%(n=92)$ were either asymptomatic or had mild disease, $2.0 \%(n=2)$ had severe disease and 6.0\% $(n=6)$ had critical disease that resulted in death ${ }^{4}$.

\section{Treatment}

In the absence of an effective anti-viral therapy, supportive care is the mainstay of treatment. Several drugs that are used for other medical conditions such as hydroxychloroquine (HCQ), macrolides, antiviral drugs; remdesivir and favipiravir have been used by clinicians across the globe to treat COVID-19 patients $^{5-8}$. The Expert Committee on Guideline development in Sri Lanka recommended the use of HCQ on all COVID-19 patients ${ }^{9}$, a decision based on limited available evidence ${ }^{5,6}$. No other antivirals are recommended for use in Sri Lanka. There is widely divided opinion in the world on the efficacy of HCQ. The Solidarity Trial, which was launched by the WHO will compare four treatment options against standard care to discover whether any of these drugs are effective against COVID-196.

Convalescent plasma had been studied in other respiratory viral infections including SARS-CoV-1 and H1N1 influenza epidemics ${ }^{11,12}$. It has been approved for use in COVID-19 patients as an investigational drug by the FDA ${ }^{13}$. We used convalescent plasma on three critically ill patients and one patient recovered. Plasma from few recovered COVID-19 patients, who have consented for donation, has been collected and stored for future use.

Tocilizumab, an interleukin-6 inhibitor, has shown to cause a marked decline in inflammatory markers, radiological improvement and reduced ventilatory support requirements when treated along with concomitant investigational antiviral agents ${ }^{14,15}$. We treated three critically ill patients with Tocilizumab.

There is emerging evidence that almost all of the severe and critical ill COVID-19 cases present with coagulation abnormalities and risk of thrombosis. Venous thromboembolism (VTE) has frequently been reported as a potential cause of unexplained deaths ${ }^{16,17}$. However, the pharmacological management of VTE in COVID-19 is complex and challenging due to the risk of bleeding. Low molecular weight heparin (LMWH) is recommended in moderate and severe disease in the VTE prophylaxis dose while for critically ill patients an increased dose is recommended ${ }^{18,19}$. We used LMWH prophylaxis dose for patients with moderate illness while the dose was doubled in critically ill patients.

SARS-CoV-2 is known to utilize angiotensin converting enzyme 2 (ACE2) receptors for entry into the target cells. Hence, there are concerns that the use of angiotensin converting enzyme inhibitors (ACEIs) and angiotensin receptor blockers (ARBs) could enhance the susceptibility for COVID-19 and also increase the mortality. A rapid review of available evidence showed that patients on long-term therapy with ACEls or ARBs are not at higher risk of poor outcomes from COVID$19^{20}$. As per the current recommendations we continued ACEIs or ARBs in those who are already taking them and if new onset of hypertension was detected they were given either beta blockers or calcium channel blockers.

\section{Outcome}

By $25^{\text {th }}$ of May, 240 patients were discharged after recovery and 2 patients were transferred out: one for drainage of an abscess in the leg and the other for hemodialysis. 79 still remain as in-patients. Some of them have persistent PCR positivity in samples taken from nasopharynx despite clinical recovery. 06 patients died including one patient who was dead on admission. Details of the deaths given in table 4 .

\section{Summary}

A large majority of our patients were either asymptomatic or mildly symptomatic. Common symptoms were fever and cough and the presentations were similar to common viral respiratory tract infections. Prognosis was poor in critically ill patients. Management strategies of severe and critically ill patients are still uncertain and under evaluation in many countries. 
Table 4. Details of deaths occurred at NIID

\begin{tabular}{llllll}
\hline & Patient 1 & Patient 2 & Patient 3 & Patient 4 & Patient 5 \\
\hline Age (years) & 60 & 50 & 80 & 48 & 44 \\
\hline Sex & Male & Male & Male & Male & Female \\
\hline Co-morbidities & $\begin{array}{l}\text { Hypertension, } \\
\text { Diabetes, CKD, } \\
\text { (KT 7yrs back) }\end{array}$ & $\begin{array}{l}\text { Diabetes } \\
\text { mellitus } \\
\text { Hypertension } \\
\text { Hypothyroidism }\end{array}$ & $\begin{array}{l}\text { Diabetes } \\
\text { IHellitus } \\
\text { I yrs back })\end{array}$ & Hypertension & None known \\
\hline $\begin{array}{l}\text { Day of illness } \\
\text { on admission }\end{array}$ & 07 & 03 & 05 & 03 & 30 \\
\hline $\begin{array}{l}\text { Duration of } \\
\text { hospital/ } \\
\text { ICU stay }\end{array}$ & $13 / 07$ & $18 / 09$ & $09 / 09$ & $25 / 20$ & 8 hours/ \\
\hline
\end{tabular}

\section{References}

1. WHO Timeline - COVID-19. https://www.who.int/newsroom/detail/27-04-2020-who-timeline-Covid-19

2. Coronavirus disease 2019 (COVID-19) - Situation Report. Epidemiology unit, Ministry of Health, Sri Lanka https:// www.epid.gov.lk/web/images/pdf/corona_virus_report/ sitrep-sl-en-31-05_10.pdf

3. Wu Z, McGoogan JM. Characteristics of and important lessons from the coronavirus disease 2019 (COVID-19) outbreak in China: summary of a report of 72-314 cases from the Chinese Centre for Disease Control and Prevention. JAMA 2020; 323(13): 1239-42. doi:10.1001/jama. 2020.2648

4. Clinical and Epidemiological Characteristics of the Confirmed COVID-19 Patients in Sri Lanka. Status Report Based on the Interim Analysis of the First 100 COVID-19 Patients Following Hospital Discharge or Death. Ministry of Health and Indigenous Medical Services, Colombo, Sri Lanka, 10th May 2020.

5. Gao J, Tian Z, Yang X. Breakthrough: chloroquine phosphate has shown apparent efficacy in treatment of COVID-19 associated pneumonia in clinical studies. Bioscience Trends 2020; 14(1): 72-3. doi: https://doi.org/10.5582/bst. 2020.01047

6. Zhonghua Jie, He He Hum Xi Za Zhi Expert Consensus on Chloroquine Phosphate for the Treatment of Novel Coronavirus Pneumonia 2020 Feb 20; 43(0): E019 doi: 10.3760/cma.j.issn.1001-0939.2020.0019
7. Wang $\mathrm{M}, \mathrm{Cao} \mathrm{R}$, Zhang $\mathrm{L}$, et al. Remdesivir and chloroquine effectively inhibit the recently emerged novel coronavirus (2019-nCoV) in vitro. Cell Research 2020; 30: 269-71.

8. Cai Q, Yang M, Liu D, et al. Experimental Treatment with Favipiravir for COVID-19: An Open-Label Control Study [published online ahead of print, 2020 Mar 18]. Engineering (Beijing). 2020;10.1016/j.eng.2020.03.007. doi:10.1016/ j.eng.2020.03.007

9. Ceylon College of Physicians and Epidemiology Unit. Provisional Clinical Guidelines on COVID-19 suspected and confirmed patients. Colombo: Ministry of Health (Accessed on 25th May 2020). https://ccp.lk/wp-content/uploads/2013/ 04/COVID-19-CPG-VERSION-5-30.04.2020_Draft-min.pdf

10. Solidarity clinical trial for COVID-19 treatments. World Health Organization. https://www.who.int/emergencies/diseases/ novel-coronavirus-2019/global-research-on-novelcoronavirus-2019-ncov/solidarity-clinical-trial-for-covid-19treatments

11. Cheng, Y., Wong, R., Soo, Y.O.Y. et al. Use of convalescent plasma therapy in SARS patients in Hong Kong. European Journal of Clinical Microbiology and Infectious Diseases. 2005.24, 44-46. https://doi.org/10.1007/s10096-004-12719

12. Hung IF, To KK, Lee CK, et al. Convalescent plasma treatment reduced mortality in patients with severe pandemic influenza A (H1N1) 2009 virus infection. Clinical infectious Diseases 2011; 52(4): 447-56. doi:10.1093/cid/ciq106 
13. Recommendations for Investigational COVID-19 Convalescent Plasma. US Food \& Drug Administration. https:/ /www.fda.gov/vaccines-blood-biologics/investigationalnew-drug-ind-or-device-exemption-ide-process-cber/ recommendations-investigational-covid-19-convalescentplasma.

14. Rand Alattar R, Ibrahim TBH, Shaar SH, et al. Tocilizumab for the treatment of severe coronavirus disease 2019. Journal of Medical Virology 2020. https://doi.org/10.1002/jmv.25964

15. Toniati P, Piva S, Cattalini $\mathrm{M}$, et al, Tocilizumab for the treatment of severe COVID-19 pneumonia with hyperinflammatory syndrome and acute respiratory failure: A single center study of 100 patients in Brescia, Italy Autoimmunity Reviews. 2020; 19(7), 102568 https://doi.org/10.1016/j.autrev.2020.102568

16. Chen N, Zhou M, Dong X, et al. Epidemiological and clinical characteristics of 99 cases of 2019 novel coronavirus pneumonia in Wuhan, China: a descriptive study. Lancet 2020; 395(10223): 507-13.

17. Tang N, Li D, Wang X, Sun Z. Abnormal coagulation parameters are associated with poor prognosis in patients with novel coronavirus pneumonia. Journal of Thrombosis and Haemostasis 2020; 18(04): 844-7.

18. Zhai Z, Li C, Chen Y, et al. Prevention and Treatment of Venous Thromboembolism Associated with Coronavirus Disease 2019 Infection: A Consensus Statement before Guidelines. Thrombosis and Haemostasis 2020 Apr 21. doi: 10.1055/s-0040-1710019.

19. Barnes GD, BurnettA, Allen A et al. Thromboembolism and anticoagulant therapy during the COVID-19 pandemic: interim clinical guidance from the anticoagulation forum. Journal of Thrombosis and Thrombolysis 2020;1-10. doi:10.1007/ s11239-020-02138

20. COVID-19 and the use of angiotensin-converting enzyme inhibitors and receptor blockers. Scientific Brief 7 May 2020. Geneva: World Health Organization; 2020 https:// www.who.int/news-room/commentaries/detail/covid-19and-the-use-of-angiotensin-converting-enzyme-inhibitorsandreceptor-blockers, accessed 25th May 2020. 